Article

\title{
Environmental Factors, More Than Spatial Distance, Explain Community Structure of Soil Ammonia-Oxidizers in Wetlands on the Qinghai-Tibetan Plateau
}

\author{
Wen Zhou ${ }^{1,2,+}$, Xiaoliang Jiang ${ }^{1,3,+}$, Jian Ouyang 1,4,5, Bei Lu ${ }^{1}(\mathbb{D}$, Wenzhi Liu 1,2,6,*(D) and \\ Guihua Liu 1,2,6,* \\ 1 CAS Key Laboratory of Aquatic Botany and Watershed Ecology, Wuhan Botanical Garden, \\ Chinese Academy of Sciences, Wuhan 430074, China; zhouwen@wbgcas.cn (W.Z.); jiangxl@wbgcas.cn (X.J.); \\ ouyangjian07@foxmail.com (J.O.); lubei@wbgcas.cn (B.L.) \\ 2 Hubei Key Laboratory of Wetland Evolution \& Ecological Restoration, Wuhan Botanical Garden, \\ Chinese Academy of Sciences, Wuhan 430074, China \\ 3 College of Life Science, University of Chinese Academy of Sciences, Beijing 100049, China \\ 4 Research Center for Ecology and Environment of Qinghai-Tibetan Plateau, Tibet University, \\ Lhasa 850000, China \\ 5 College of Science, Tibet University, Lhasa 850000, China \\ 6 Center for Plant Ecology, Core Botanical Gardens, Chinese Academy of Sciences, Wuhan 430074, China \\ * Correspondence: liuwz@wbgcas.cn (W.L.); liugh@wbgcas.cn (G.L.) \\ $\dagger$ These authors contributed equally to this work.
}

Received: 26 April 2020; Accepted: 18 June 2020; Published: 21 June 2020

\begin{abstract}
In wetland ecosystems, ammonia oxidation highly depends on the activity of ammonia-oxidizing archaea (AOA) and ammonia-oxidizing bacteria (AOB), which are, therefore, important for studying nitrogen cycling. However, the ammonia-oxidizer communities in the typical high-elevation wetlands are poorly understood. Here, we examined ammonia-oxidizer communities in soils from three wetland types and 31 wetland sites across the Qinghai-Tibetan Plateau. The amo $A$ gene of AOA and AOB was widespread across all wetland types. Nitrososphaera clade (Group I.1b) overwhelmingly dominated in AOA community (90.36\%), while Nitrosospira was the principal AOB type (64.96\%). The average abundances of AOA and AOB were $2.63 \times 10^{4}$ copies g $^{-1}$ and $9.73 \times 10^{3}$ copies $\mathrm{g}^{-1}$. The abundance of AOA amoA gene was higher in riverine and lacustrine wetlands, while $\mathrm{AOB}$ amoA gene dominated in palustrine wetlands. The environmental conditions, but not spatial distance, have a dominant role in shaping the pattern of ammonia-oxidizer communities. The AOA community composition was influenced by mean annual temperature (MAT) and mean annual precipitation (MAP), while MAT, conductivity and plant richness, $\mathrm{pH}$, and TN influenced the $\mathrm{AOB}$ community composition. The net nitrification rate had a significant correlation to $\mathrm{AOB}$, but not AOA abundance. Our results suggest a dominant role for climate factors (MAT and MAP) in shaping community composition across a wide variety of wetland sites and conditions.
\end{abstract}

Keywords: nitrification; the Qinghai-Tibet Plateau; high-elevation wetland; microbial community structure

\section{Introduction}

Nitrification is the biological oxidation of ammonia into nitrate [1] and it plays essential roles in the wetland nitrogen cycle and $\mathrm{N}_{2} \mathrm{O}$ production. Ammonium oxidation, as the first and rate-limiting step of nitrification, was mainly catalyzed by ammonia-oxidizing bacteria and ammonia-oxidizing 
archaea [2,3]. Both groups of taxa perform a similar function of ammonia monooxygenase enzymatic pathway; therefore, the $a m o A$ gene is commonly used as a functional marker for ecological assessment of these taxa $[2,4]$. However, many previous studies suggested that their relative abundances vary from fractional to several orders of magnitude, depending upon a variety of environmental factors-such as $\mathrm{pH}$, salinity, organic carbon, temperature, ammonium and moisture content [5-10]. For instance, AOA dominates nitrification in low ammonium, low $\mathrm{pH}$, and high temperature environments, while AOB dominates nitrification in high ammonium and low temperature environments [5,11-14].

While many studies have demonstrated that AOA and AOB are widely distributed and regulated by the environment factors [15], less is known regarding the ammonia-oxidizer community in high-elevation wetland ecosystems. We do not know whether high-elevation wetlands have microbial aspects that are similar to other wetlands or if their microbial community structure and function are unique. Two previous studies have investigated ammonia-oxidizer communities in the overlying water and sediments of five rivers in the Qinghai-Tibetan Plateau, and found that the high-elevation conditions (low temperature, low ammonium concentration, and intensive solar radiation) shaped distinctive community compositions and distribution patterns for ammonia oxidizers in the five rivers, as compared with low-elevation rivers $[10,16]$. These observations highlight the necessity of better understanding how a wider range environmental condition can regulate ammonia-oxidizer communities. However, it is unknown whether these findings are applicable to other high-elevation wetlands.

The wetland on the Qinghai-Tibetan Plateau is the largest high-elevation wetland region on earth, holding over $131,894 \mathrm{~km}^{2}$ of area and accounting for approximately $20 \%$ of wetlands in China [17]. There are various types of wetland ecosystems in the Qinghai-Tibetan plateau, such as riverine, lacustrine, and palustrine wetlands, according to hydrologic connection, soil moisture, and vegetation [18]. These wetlands are the major nitrogen sinking pools and they have a high sensitivity of environmental changes [19]. Plateau wetlands typically show a sharp decrease of temperature and nitrogenous compounds, but an intensive increase of solar radiation, due to its unique high-elevation conditions and the low human disturbance.

In the present study, we investigated 31 natural wetlands from three wetland types on the Qinghai-Tibetan Plateau. For these 31 wetlands, the average elevation is higher than $4000 \mathrm{~m}$ above sea level, and the distance between sites reached upwards of $2457 \mathrm{~km}$. Moreover, the environmental settings were highly heterogeneous. For example, the soil conductivity ranged from 61 to $2848 \mu \mathrm{cm} \mathrm{cm}^{-1}$, and the average temperature from $-3.52^{\circ} \mathrm{C}$ to $17.62^{\circ} \mathrm{C}$. Given these novel environmental characteristics, we reported the abundance, composition, and diversity of ammonia-oxidizer communities in wetland sediments, and examined their correlations with geographic distance and potential environmental factors. Specific questions we address include: (1) what are the compositions and relative abundances of microbial communities in alpine wetland sediments? (2) How do microbial communities vary across geographic distance and environmental gradients? And (3) what are the key drivers if such variations exist?

\section{Materials and Methods}

\subsection{Study Area and Sampling}

The elevation of our study area ranges from 254 to $5151 \mathrm{~m}$ and the latitude lies between 28.16 and $37.46^{\circ}(\mathrm{N})$. A total of 31 isolated wetlands situated in both Qinghai Province and the Tibetan autonomous Region of China were selected, covered a wide range stretching $1034 \mathrm{~km}$ from north to south and $2457 \mathrm{~km}$ from east to west (Figure 1). These wetlands are in varied hydrological and physicochemical environments, encompassing 18 lacustrine (lake margin), seven riverine, and six palustrine wetlands, respectively (Online Resource 1), based on the definition developed by Tammi [20]. Surface soils $(0-5 \mathrm{~cm})$ of each wetland site were sampled with a 5 -cm-diameter hand corer. Each composite soil sample was randomly collected from five selected locations in a $1 \mathrm{~m}^{2}$ plot. After being passed through a $2 \mathrm{~mm}$ sieve to remove the plant residues, root fragments, and gravel, these five soil samples were mixed 
and homogenized, and were then subdivided into two subsamples. One was stored at approximately $5{ }^{\circ} \mathrm{C}$ in a portable refrigerator to determine the soil properties, and the other was stored in liquid nitrogen prior to DNA extraction. Surface water samples (upper $50 \mathrm{~cm}$ ) were collected in each site for water quality determination. The water samples were stored at approximately $5{ }^{\circ} \mathrm{C}$ for property testing.

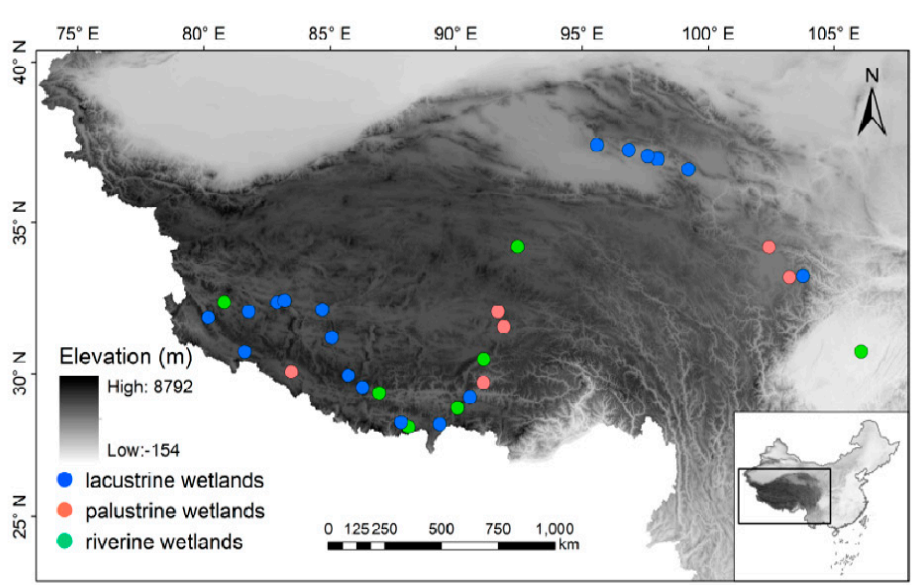

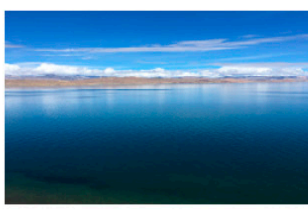

Lacustrine

wetland

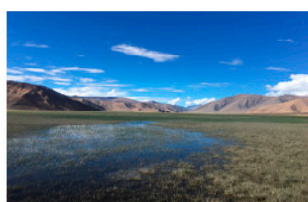

Palustrine

wetland

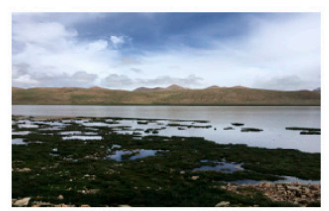

Riverine

wetland

Figure 1. Location of the 31 wetlands on the Qinghai-Tibetan Plateau investigated in this study.

\subsection{Vegetation Survey and Measurements of Environmental Factors}

At each sampling site, the latitude, longitude, and elevation were recorded. The mean annual temperature and mean annual precipitation of each site were extracted by interpolation [21] from a 1-km resolution climate dataset of the Chinese ecosystem research network (CERN) in ArcGIS 10.0 (ESRI Inc., Redlands, CA, USA). The plant species richness of each site was taken as the total number of recorded vascular plants per $1 \mathrm{~m}^{2}$ plot. The plant coverage was visually estimated in each quadrat while using a $1 \times 1 \mathrm{~m}$ grid frame, which was divided into $10 \times 10 \mathrm{~cm}$ squares [22].

Water temperature, $\mathrm{pH}$, and electrical conductivity were determined in situ with a Multi-Parameter Water Quality Sonde (YSI 6920, Yellow Springs, OH, USA) at a depth of $50 \mathrm{~cm}$ below the water surface. Samples for the total nitrogen (TN), total carbon (TC), and total organic carbon (TOC) measurement were analyzed with a total organic carbon analyzer (Shimadzu TOC-Vc series, Tokyo, Japan) that was equipped with a total nitrogen module. The concentration of total phosphorus (TP) was determined using the colorimetric method with a spectrophotometer (UV-1800, Shimadzu, Tokyo, Japan) after digestion by potassium peroxydisulfate solution.

Soil temperature at $5 \mathrm{~cm}$ depth of each wetland site was measured using a thermometer with a stainless probe. In the laboratory, soil $\mathrm{pH}$ and electrical conductivity were determined in soil water extract ( $1: 5 \mathrm{w} / \mathrm{v}$ soil to water ratio) while using a $\mathrm{pH} /$ conductivity meter. Soil moisture content was gravimetrically assessed by drying the soil at $105{ }^{\circ} \mathrm{C}$ until constant mass was reached. Soil total carbon (STC) and total nitrogen (STN) were measured with an elemental analyzer (Vario TOC cube, Hanau, Germany). The concentration of soil total phosphorus (STP) was measured by the molybdenum blue method with a spectrophotometer (Shimadzu, Tokyo, Japan) after digestion. The soil ammonium $\left(\mathrm{SNH}_{4}{ }^{+}\right)$and nitrate $\left(\mathrm{SNO}_{3}{ }^{-}\right)$were determined with a continuous flow auto-analyzer (EasyChem Plus, Systea, Italy).

\subsection{Determination of Soil Nitrification Rate}

The soil nitrification rates were determined using the shaken-slurry method, as described by Hart et al. [23]. Specifically, $5 \mathrm{~g}$ of fresh soil from each site were weighted into a $250 \mathrm{~mL}$ sterile Erlenmeyer flask. $100 \mathrm{~mL}$ of a $1 \mathrm{mM}$ phosphate buffer $(\mathrm{pH} 7.4)$ and $0.5 \mathrm{~mL}$ of a $0.25 \mathrm{M}\left(\mathrm{NH}_{4}\right)_{2} \mathrm{SO}_{4}$ solution were added to allow gas exchange during the nitrification process. All of the flasks were incubated on an orbital shaker with a $180 \mathrm{rpm}$ speed at room temperature for $24 \mathrm{~h}$. $10 \mathrm{~mL}$ subsamples 
were removed from the slurry at $1,4,10,16$, and $24 \mathrm{~h}$ after the start of incubation, and then filtrated through glass microfiber filters (Whatman, UK) after centrifugation at $3000 \mathrm{rpm}$ for $5 \mathrm{~min}$. The concentrations of $\mathrm{NH}_{4}{ }^{+}$and $\mathrm{NO}_{3}{ }^{-}$in filtrate were measured by automatic nutrient analyzer (EasyChem plus, Systea, Italy). Because the nitrite concentrations were negligible in the incubations, the potential nitrification rate (PNR) was calculated as the change in $\mathrm{NO}_{3}{ }^{-}$concentration per unit time. The determination of net nitrification rate (NNR) was followed the same protocol as PNR, except that the phosphate buffer and $\left(\mathrm{NH}_{4}\right)_{2} \mathrm{SO}_{4}$ solution were replaced by $100 \mathrm{~mL}$ in situ water.

\subsection{DNA Extraction, Amplification, Cloning and Sequence Analysis for Ammonia-Oxidizing Genes}

Genomic DNA was extracted from approximately $0.2 \mathrm{~g}$ of mixed soil subsamples while using a PowerSoil DNA Isolation Kit (MoBio Laboratories, Inc., Carlsbad, CA, USA) according to the manufacturer's protocol. The DNA concentrations were spectrophotometrically measured with a NanoDrop 2000 (Thermo Fisher Scientific, Waltham, MA, USA). We further confirmed the intact DNA by electrophoresis on a 1\% TAE-agarose gel. The primer pairs Arch-amoAF/Arch-amoAR [24] and amoA-1F/amoA-2R [25] were adopted to amplify and construct the clone libraries of AOA- and AOB-amoA (ammonia monooxygenase subunit A) genes, respectively. The sequences of primers and thermal cycling procedures are shown in Online Resource 2. Each reaction was performed in a $25 \mu \mathrm{L}$ volume consisting of $1 \mu \mathrm{L}$ of DNA template $(10-100 \mathrm{ng} / \mu \mathrm{L}), 0.5 \mu \mathrm{L}$ of each primer $(10 \mathrm{mM})$, $0.2 \mu \mathrm{L}$ of rTaq polymerase ( $5 \mathrm{U} / \mu \mathrm{L}$ ) (TaKaRa, DaLian, China), $0.5 \mu \mathrm{L}$ of deoxynucleotide triphosphates (dNTP, $10 \mathrm{mM}$ ), and $2.5 \mu \mathrm{L}$ of $10 \times$ buffer. The PCR product was gel-purified and then ligated into the pMD18-T vector (TaKaRa, DaLian, China), which was transformed into Trans- $5 \alpha$ competent cells (TransGen Biotech, Beijing, China) and then incubated at $37^{\circ} \mathrm{C}$ for about $14 \mathrm{~h}$. The insertion of an appropriate-sized DNA fragment was determined by PCR amplification with the primer set M13F and M13R (Sangon Biotech Co., Ltd., Shanghai, China).

Approximately sixty positive clones with the correct size from each site were selected for sequencing while using ABI-3730XL automated sequencer (Applied Biosystems, Foster City, CA, USA) by Sangon Biotech Co., Ltd. Sequences with poor-quality or insufficient length were discarded by Geneius Pro 8.0.2 software (Biomatters Ltd., Auckland, New Zealand), and other sequences were aligned using MAFFT program [26]. The sequences sharing $97 \%$ similarity were grouped into the same operational taxonomic unit (OTU) while using the program Mothur with the furthest neighbor algorithm [27]. Rarefaction analysis was performed by using Mothur to show whether the majority of OTUs was already covered by sampling. The taxonomic identities of the main OTUs (at least containing two clones) of $\mathrm{AOA}$ and $\mathrm{AOB}$ were determined by constructing phylogenetic trees with reference sequences obtained from the National Centre for Biotechnology Information (NCBI) database while using MEGA v7 [28]. Bootstrap analysis was used to estimate the reliability of phylogenetic reconstructions (1000 replicates). The archaeal and bacterial amoA sequence data reported are available in the GenBank database under the accession numbers MG574595-MG574721 (for archaeal amoA) and MG574722-MG574819 (for bacterial amoA).

\subsection{Real-Time Quantitative PCR}

Copy numbers of the amoA gene of ammonia-oxidizing bacteria and archaea were determined in triplicate while using Roche LightCycler480 software version 1.5 with the fluorescent dye SYBR green quantitative PCR method. The Arch-amoA and $a m o A$ gene fragments were amplified using the primer sets Arch-amoAF/Arch-amoAR and amoA-1F/amoA-2R, respectively. qPCR amplification was performed in a $25-\mu \mathrm{L}$ reaction mixture that consisted of $10 \mu \mathrm{L}$ of SybrGreen qPCR Master Mix (2x), $1 \mu \mathrm{L}$ of each primer $(10 \mu \mathrm{M})$, and $2 \mu \mathrm{L}$ of template DNA. The primers and qPCR thermal profiles are listed in Online Resource 2. The positive colonies confirmed that Arch-amoA and amoA genes were successfully ligated into the pMD18-T vector (TaKaRa, Dalian, China). The plasmid DNA was extracted from the positive colony using the SK8191 SanPrep Kit (Sangon Biotech Co., Ltd., Shanghai, China). The concentration of the plasmid DNA was measured on a Nanodrop 2000 spectrophotometer (Thermo 
Fisher Scientific, Waltham, USA). Standard curves were constructed with ten-fold serial dilutions of a known amount of plasmid DNA involving the target genes. For all assays, the amplification efficiencies were $89-110 \%$ and $\mathrm{R}^{2}$ values were all over 0.99 .

\subsection{Definition of Abundant and Rare Taxa}

For the definitions of abundant and rare communities, we followed the most-applied definitions in recent literature that combined their local and regional relative abundances [29]. The abundant OTUs were defined as those with a relative abundance of $>1 \%$ in local samples and a mean relative abundance of $>0.1 \%$ in all samples. The OTUs that had a mean relative abundance of $<0.01 \%$ in local samples and the mean relative abundances of $<0.001 \%$ in all samples were defined as regionally rare OTUs.

\subsection{Statistical Analyses}

Alpha diversity (expressed as OTU richness, evenness and Shannon index) of each sample was calculated in R (3.5.2) with vegan package [30]. Kruskal-Wallis H test was used to compare the difference in gene abundance between ammonia-oxidizing archaea and bacteria, and also be used to estimate the differences in alpha diversity among the three wetland types, because the data failed the normality test. The relationships of geographical distance and sample ordination on taxonomic (Bray-Curtis distance), as well as environmental dissimilarity (Euclidean distance based on 19 environmental variables) were investigated based on the Mantel test with 999 permutations [30]. Non-metric multidimensional scaling (NMDS) ordination was performed based on unweighted Unifrac distances by using GUniFrac and vegan package in order to visualize the similarity of community structure among different three wetlands [31]. The principal coordinates of neighbor matrices (PCNMs) approach was used to calculate a set of spatial variables based on the longitude and latitude coordinates of each sampling site [32].

Although variation partitioning analysis (VPA) is widely used in ecological research to distinguish between environmental constraints and potential dispersal limitation, it is sometimes difficult to correctly predict the environmental and spatial components of community structure, especially in the simulation models researches [33]. Therefore, VPA, Mantel, and partial Mantel test were conducted in this study, in order to evaluate the relative importance of the selective and neutral processes in shaping the ammonia-oxidizer community. We correlated the dissimilarities of community composition with those of environmental factors using the partial Mantel test to identify the environmental drivers in the ammonia-oxidizing microbial communities. Before the analysis, the environmental variables with high variable inflation factor (VIF $>10$ ) were eliminated to limit collinearity among factors. Further, we calculated the proportionate contribution that each environmental variable made to the coefficient of determination $\left(R^{2}\right)$ in multiple regression by 'relweight' function in $R$ [34] in order to clarify the relative contribution of these drivers.

\section{Results}

\subsection{Physicochemical Properties of the Samples}

During sampling periods, soil temperatures $\left(8.8^{\circ} \mathrm{C}\right.$ to $\left.29.6^{\circ} \mathrm{C}\right)$ were significantly correlated to elevation $(r=-0.40, p<0.05, n=31)$ (online resource 3$)$. Soil conductivity significantly increased from 61 to $2848 \mu \mathrm{s} \mathrm{cm}^{-1}$ with the increase of latitude $(r=0.51, p<0.01, n=31)$. The contents of ammonium $\left(\mathrm{NH}_{4}{ }^{+}\right)$and total carbon ranged from 0.201 to $5.875 \mathrm{mg}-\mathrm{N} \mathrm{kg}^{-1}$ and from 0.453 to $13.451 \mathrm{mg} \mathrm{kg}^{-1} \mathrm{dry}^{-}$ sediment, respectively. No significant differences in the physicochemical properties were detected among wetland types $(p>0.05)$.

\subsection{Abundance of Ammonia-Oxidizing Microorganisms (AOM) and Taxonimic Classification}

A total of 1265 archaeal amoA sequences and 1567 bacterial amoA sequences were obtained, which clustered into 127 and 161 OTUs at 97\% sequence similarity level for AOA and AOB, respectively. 
The rarefaction curves showed that the vast majority of AOM taxa in the sediments of wetlands were recovered in our samples (online resource 4).

We observed that the abundance of AOA amoA of all soil samples varied between 520 and $2.36 \times 10^{5}$ copies $^{-1}$ dry soil, with the lowest and the highest values being observed in the lacustrine and riverine wetlands, respectively (Figure 2 and Online Resource 1). For the AOB amoA gene, the abundance ranged from 69.2 to $8.9 \times 10^{5}$ copies $^{-1}$ dry soil, with the lowest and the highest values being observed in the lacustrine and palustrine wetlands, respectively (Figure 2 and Online Resource 1). The average AOA abundance level of all samples $\left(2.63 \times 10^{4}\right.$ copies $\mathrm{g}^{-1}$ dry soil) was significantly higher than that of AOB $\left(9.73 \times 10^{3}\right.$ copies $^{-1}$ dry soil) (Kruskal-Wallis, $p<0.01$, Figure 2$)$. However, in specific wetland type, the average AOB abundance level of palustrine wetlands $\left(3.06 \times 10^{4}\right.$ copies $\mathrm{g}^{-1}$ dry soil) were significantly higher than that of AOA $\left(1.36 \times 10^{4}\right.$ copies $\mathrm{g}^{-1}$ dry soil).

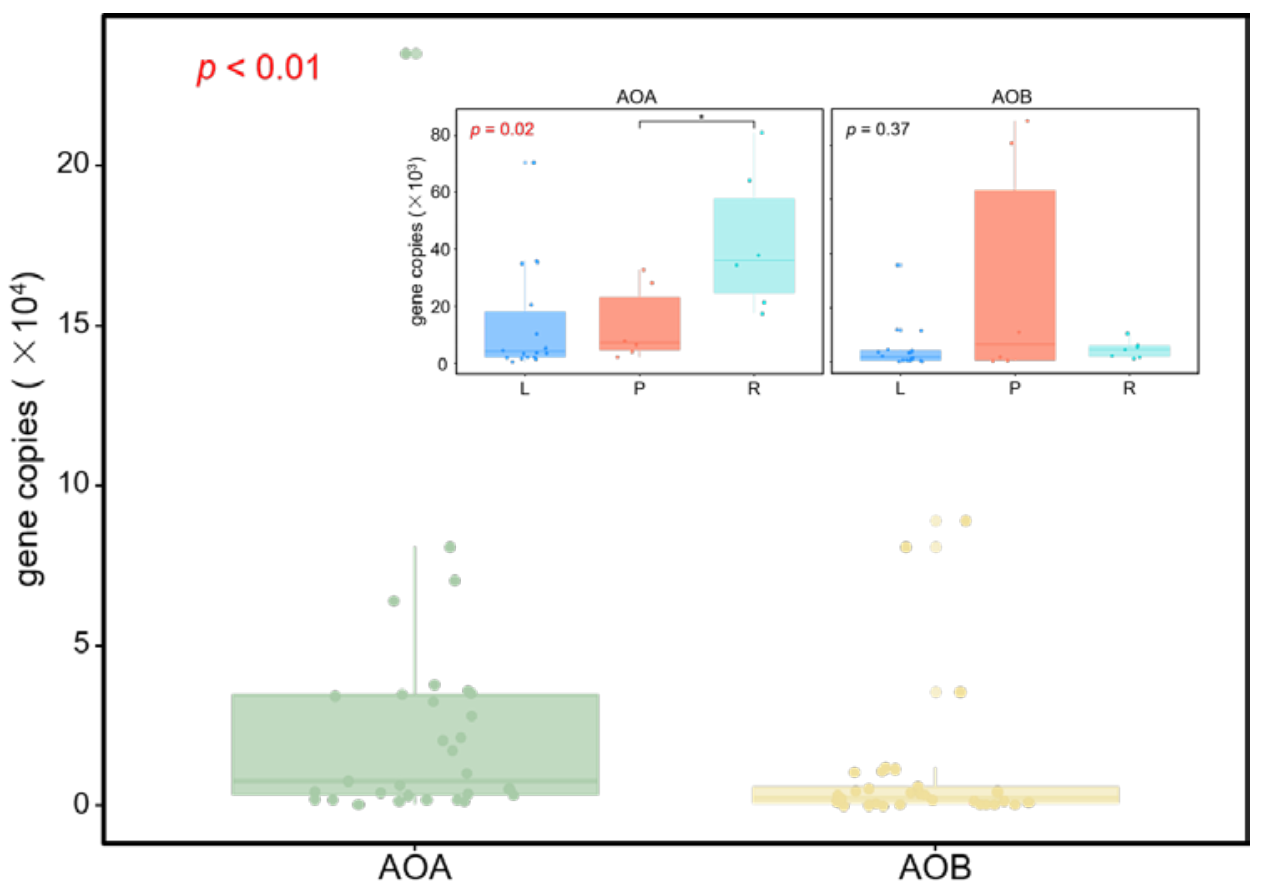

Figure 2. Abundance of ammonia-oxidizing microbe communities in soils. The graphs on the top right show the differences in abundances among lacustrine $(\mathrm{L})$, palustrine $(\mathrm{P})$, and riverine $(\mathrm{R})$ wetlands. The asterisk indicates the statistical significance between two wetland types $\left({ }^{*} p<0.05\right)$.

There were no rare OTUs observed in our study according to the definition of abundant and rare taxa. The patterns of taxonomic compositions were very similar between all and abundant taxa in AOA communities. While as for AOB communities, the percentage of unique OTUs for abundant taxa was much lower in palustrine wetlands (Online Resource 5).

According to the phylogenetic trees, the dominant $(90.36 \%)$ of AOA sequences were clustered into the Nitrososphaera clade (Group I.1b), followed by Nitrosopumilus (Group I.1a, 5.14\%). No sequence was affiliated to Nitrosotalea (the Group I.1a-associated cluster) (online resource 6A). As for AOB, $64.96 \%$ of all bacterial amoA sequences were grouped into the Nitrosospira cluster, while approximately $24 \%$ and $7 \%$ of total AOB sequences affiliated with N. eutropha and N. oligotropha, respectively (online resource 6B).

\subsection{The Nitrification Potential of Samples}

The net nitrification rate and potential nitrification rate of soil were $0.10 \pm 0.02$ and $0.37 \pm 0.02 \mathrm{mg} \mathrm{N} \mathrm{kg}^{-1}$ soil d ${ }^{-1}$, respectively, while there was no significant difference in each types of wetland (Figure 3). NNR and PNR were both significantly correlated with AOB abundance, but not 
with the abundance of AOA. When the three types of wetland were analyzed separately, the abundance of AOA from palustrine wetlands were found to strongly correlate with PNR (Figure 3).

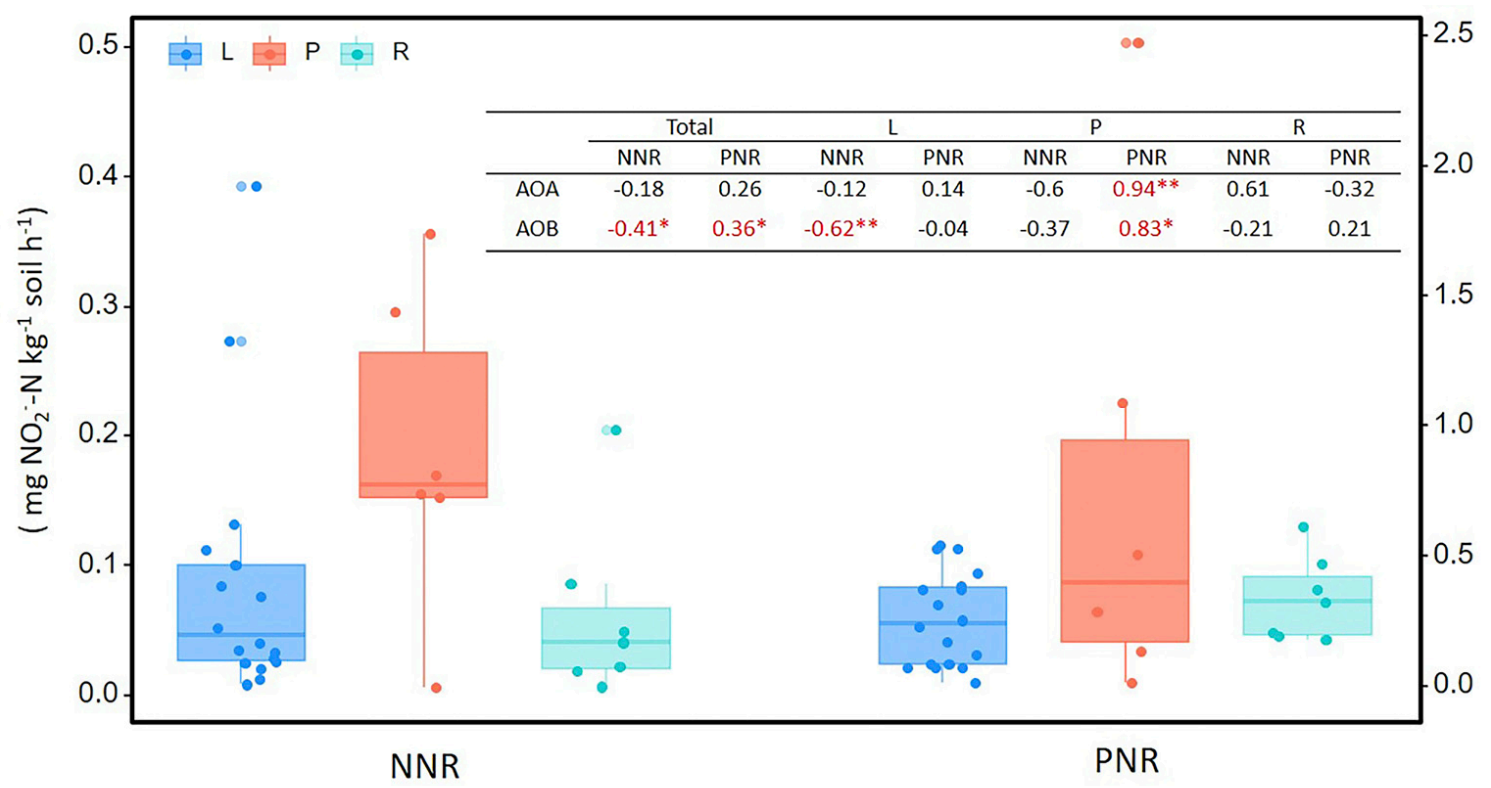

Figure 3. The net nitrification rate (NNR) and the potential nitrification rate (PNR) in soils from lacustrine $(\mathrm{L})$, palustrine $(\mathrm{P})$, and riverine $(\mathrm{R})$ wetlands. The table shows the Spearman's $\mathrm{r}$ and the statistical significance of the ammonia-oxidizers abundances correlated to NNR and PNR in total and different wetlands $(* * p<0.01, * p<0.05)$.

\subsection{Alpha-Diversity of AOM Communities}

The alpha-diversities, which were measured as OTU richness, evenness, and Shannon index, were not significantly different between archaeal and bacterial amoA genes, but it revealed significant difference among wetland types. For the AOA amoA gene, the OTU richness in riverine wetlands was significantly higher than that in lacustrine wetlands, and the Shannon index in both riverine and palustrine wetlands was significantly higher than that in lacustrine wetlands (Figure 4). For the AOB amo $A$ gene, both the OTU richness and the Shannon index in riverine wetlands were significantly higher than those in lacustrine and palustrine wetlands (Figure 4).

\subsection{Spatial Distance and Environmental Variations Associated with Patterns of AOM Community Composition}

The spatial distance in community composition estimated using beta-diversity based on Bray-Curtis distance, the Mantel test revealed significant distance-decay relationships (DDRs) of community similarity vs. geographic distance in both AOA $(r=0.201, p<0.01)$ and AOB $(r=0.276$, $p<0.01)$. Similarly, the abundant community similarities of AOA $(r=0.270, p<0.01)$ and AOB $(r=0.401, p<0.01)$ both generally declined with environmental variables (Figure 5).

Given that both spatial distance and environmental variation can be important in forming the AOM community, we attempted to explore their relative contribution. The variation partitioning analysis showed that the explained proportions of environmental factors (accounted for $66.86 \%$ and $68.18 \%$ variations in $\mathrm{AOA}$ and $\mathrm{AOB}$, respectively) were dominantly higher than spatial variables (for less than $3 \%$ of the variations) and also indicted that the pure effect of environmental factors in the AOB community tended to be a bit stronger than in AOA community (Figure 6). 

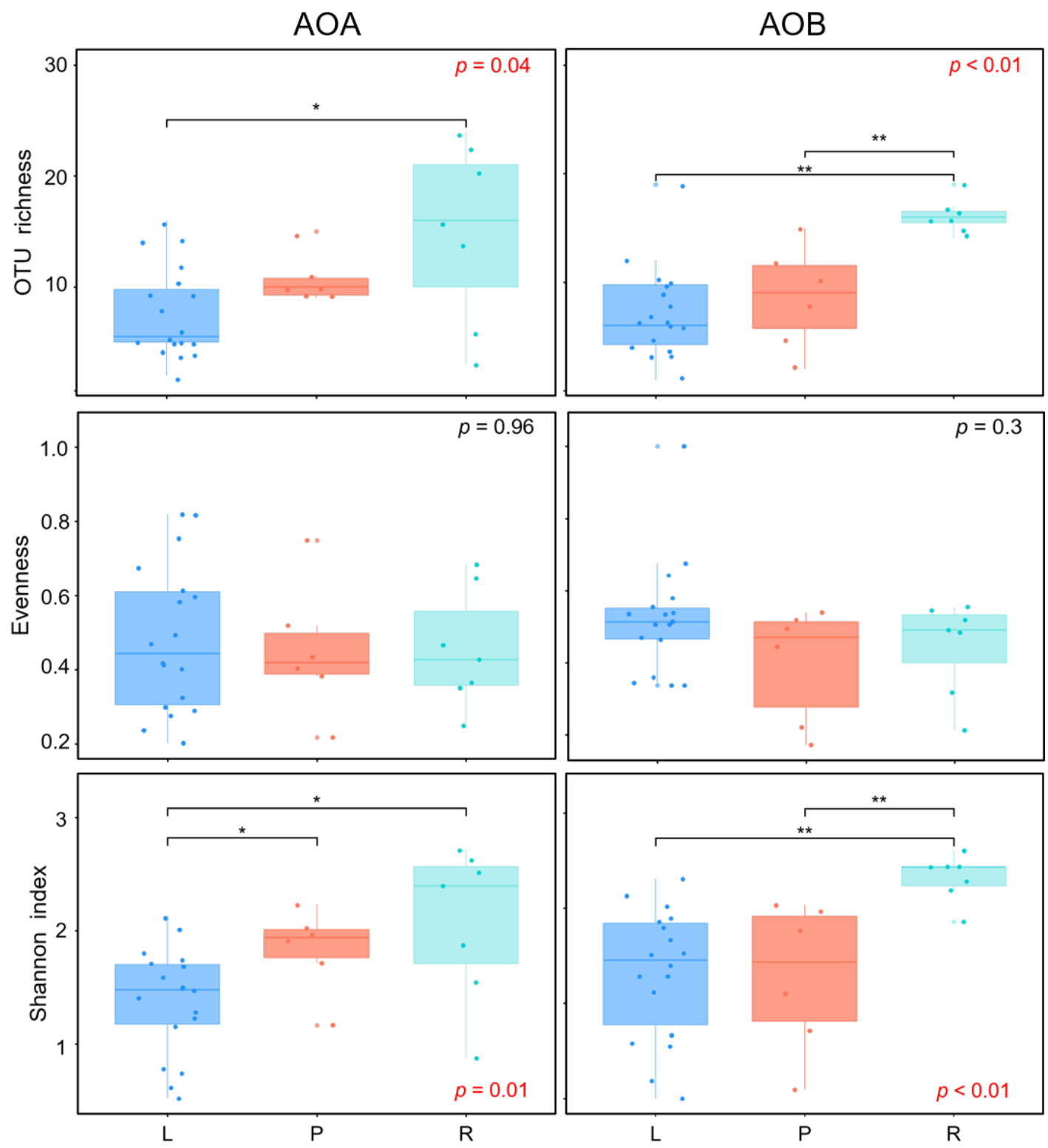

Figure 4. Alpha diversity of ammonia-oxidizing microbe communities in soils collected from lacustrine $(\mathrm{L})$, palustrine $(\mathrm{P})$, and riverine $(\mathrm{R})$ wetlands. The asterisk indicates the statistically significant between two wetland types $(* * p<0.01, * p<0.05)$. 

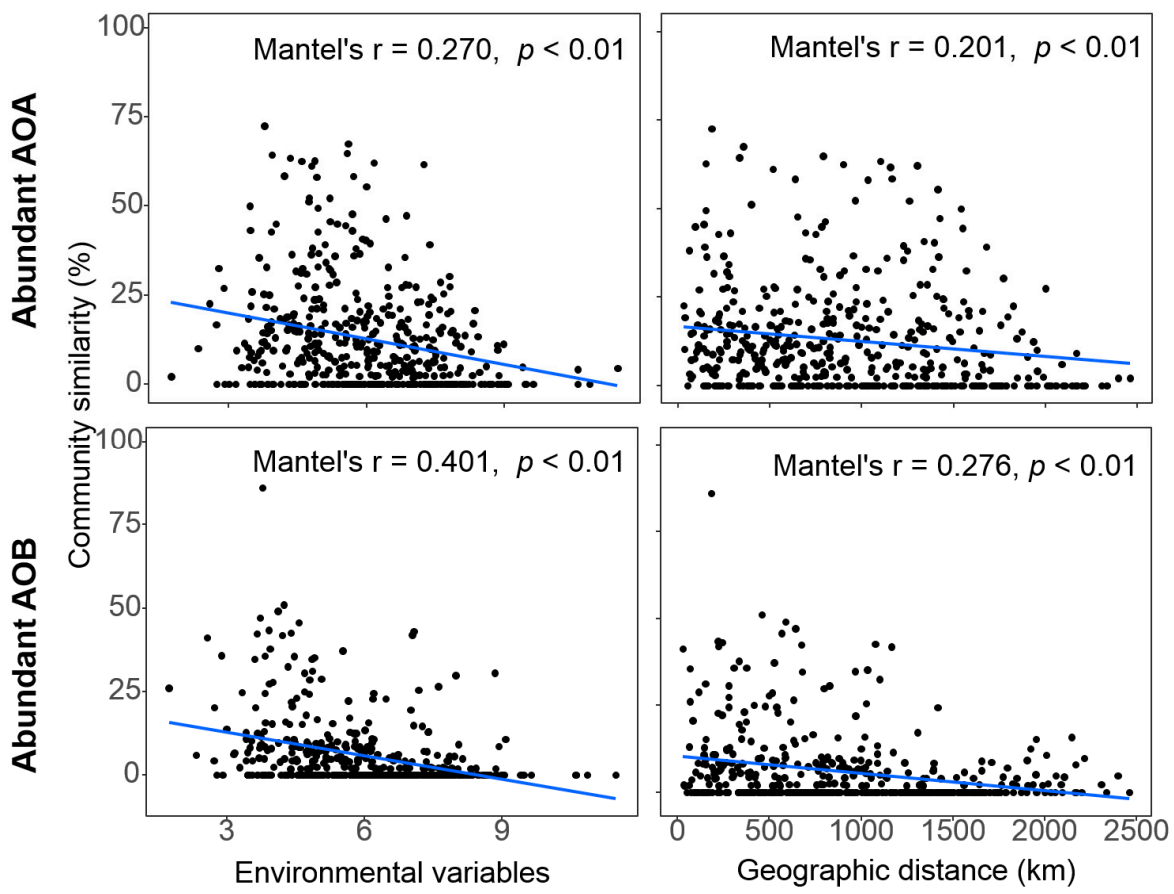

Figure 5. Spearman's rank correlation between ammonia-oxidizing microbe communities (Bray-Curtis similarity) and the Euclidean distance of environmental factors, geographic distance. The blue lines denote the linear regression across all sampling sites. The Mantel test was used to examine the correlations between the pairwise Bray-Curtis similarity and pairwise differences in environmental variables/geographic distance. All 19 environmental variables were used.

Abundant $A O A$

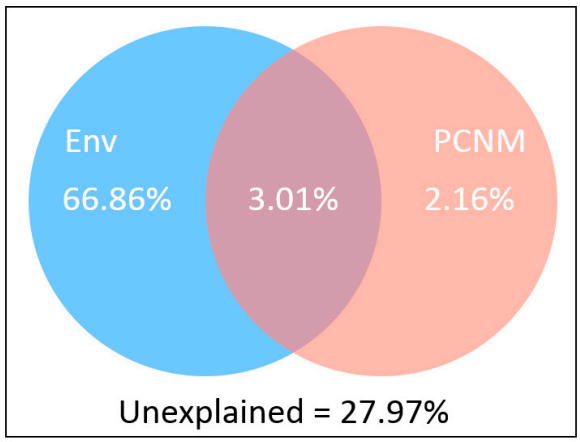

Abundant $A O B$

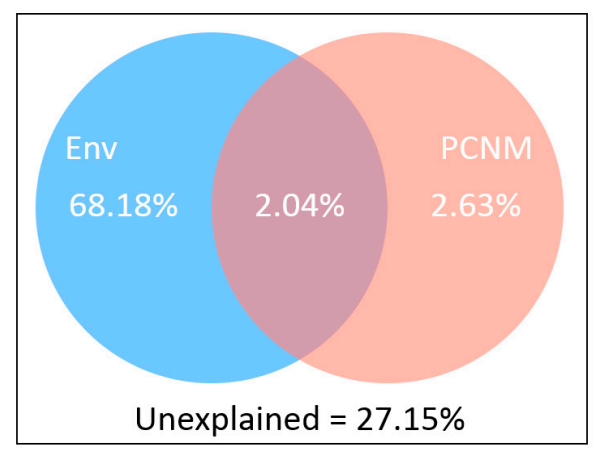

Figure 6. Variation partitioning of ammonia-oxidizing microbe communities by environmental variables (Env) and spatial factors (PCNM) for abundant communities.

\subsection{Environmental Drivers of AOM Abundance and Community Composition}

The NMDS of taxonomic compositions of ammonia-oxidizing microbes did not clearly group by wetland types (top panels in Figure 7A), but rather separated by the local soil conductivities, as shown by the significant correlations between the first axis of NMDS and soil conductivities (bottom panels in Figure 7A). Based on the performance of local soil conductivity, we inferred that the environmental variables supposed to play important roles in AOM community structures. Accordingly, we further correlated distance-corrected dissimilarities of taxonomic community composition with environmental factors while using the partial Mantel test to identify the environmental drivers of AOM community structures in our research (Figure 7B). The AOA community composition were most strongly correlated with both MAT and MAP (Mantel's $r=0.289-0.296 ; p<0.01$ ), while the soil $\mathrm{pH}, \mathrm{NO}_{3}{ }^{-}-\mathrm{N}$ and plant richness were only weakly correlated with the AOA community $(0.05<p<0.1)$ (Figure 7B). The AOB 
community assembly was strongly correlated with MAT, conductivity, and plant richness (Mantel's $r=0.197-0.361, p<0.01$ ), and correlated with pH and TN (Mantel's $r=0.127-0.225, p<0.05$ ).

\section{A}

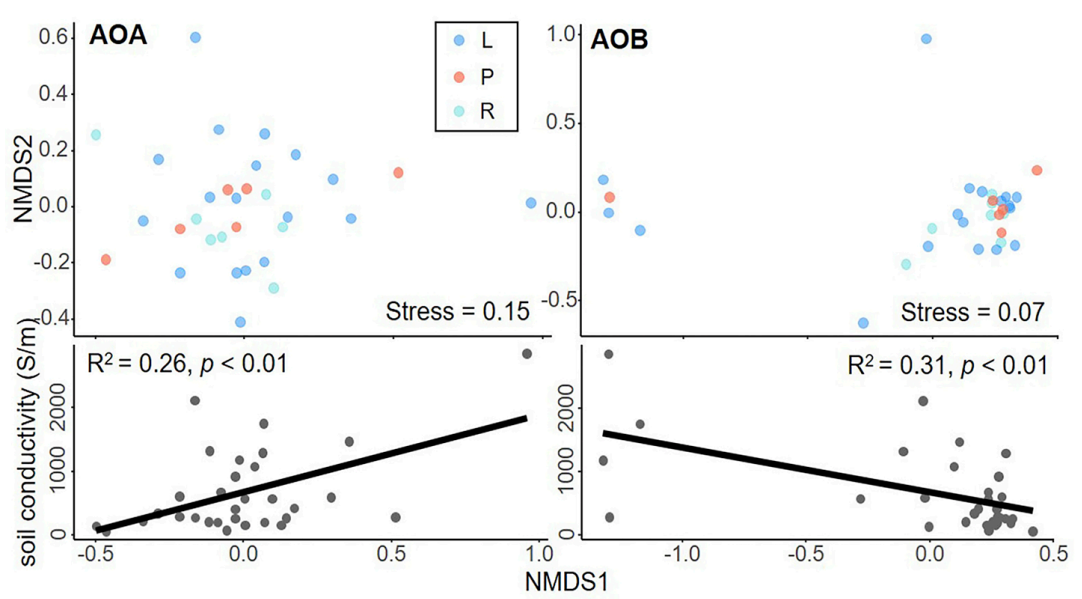

B

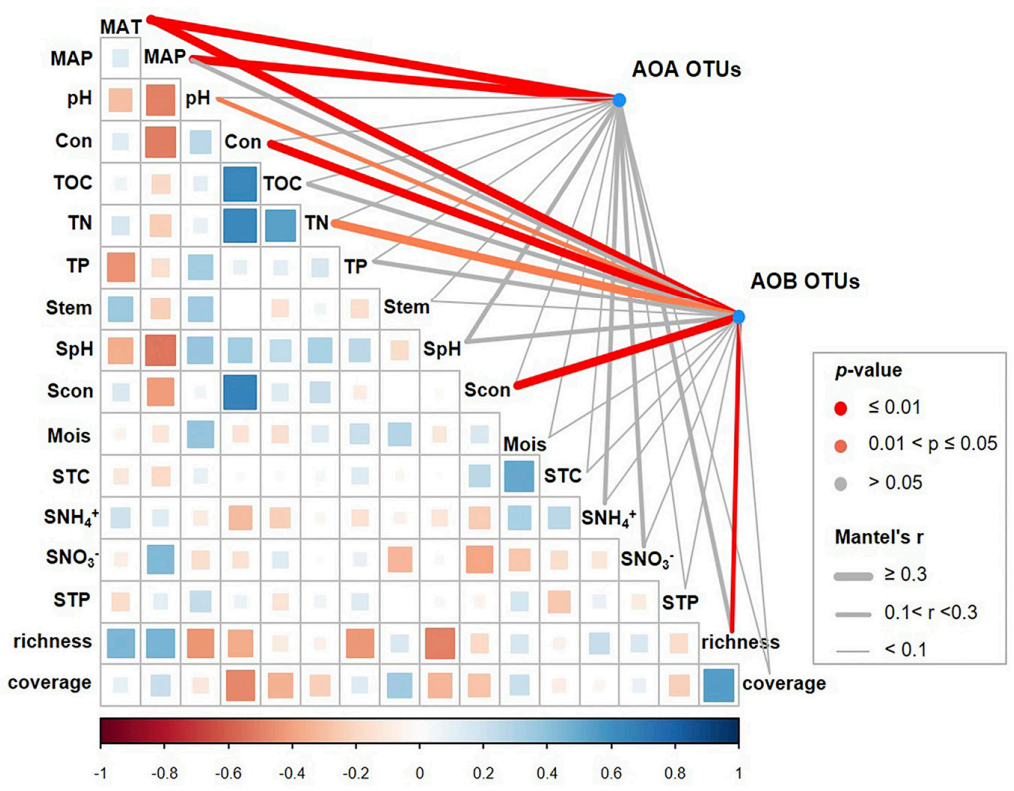

Figure 7. Environmental drivers of ammonia-oxidizing microbe community compositions. (A) Non-metric multidimensional scaling (NMDS) ordination based on unweighted Unifrac distances similarity shows that ammonia-oxidizing microbe community composition are not grouped clearly by wetland types (top), but rather separated by the local soil conductivities as shown by the significant correlations (bottom). (B) Pairwise comparisons of environmental factors are shown, with a color gradient denoting Spearman's rank correlation coefficient. Ammonia-oxidizing archaea (AOA) and ammonia-oxidizing bacteria (AOB) community composition (Bray-Curtis distance) was related to each environmental factor by partial (geographic distance corrected) Mantel test. Edge width denotes the Mantel's r statistic and the edge color corresponds to the statistical significance based on 9999 permutations. MAT: mean annual temperature; MAP: mean annual precipitation; Con: conductivity in water; TOC: total organic carbon in water; TN: total nitrogen in water; TP: total phosphorous in water; Stem: soil temperature; $\mathrm{SpH}$ : soil $\mathrm{pH}$; Scon: conductivity in soil; Mois: soil moisture; STC: total carbon in soil; $\mathrm{SNH}_{4}{ }^{+}$: soil $\mathrm{NH}_{4}{ }^{+}-\mathrm{N}$; $\mathrm{SNO}_{3}{ }^{-}$: soil $\mathrm{NO}_{3}{ }^{-}-\mathrm{N}$; STP: total phosphorous in soil; richness: plant species richness; coverage: plant coverage. 


\section{Discussion}

\subsection{Community Strucures of Ammonia-Oxidizers}

In present study, we drew a comprehensive picture about the abundances, diversities, and compositions of AOA and AOB in high-elevation wetlands. We found the identities of ammonia-oxidizer sequences from Qinghai-Tibetan wetlands are similar with the AOM compositions from other studies. For example, Nitrososphaera clade (Group I.1b) overwhelmingly dominated (90.36\%) in the AOA amoA sequences in our study, which was very close to the value (91.4\%) from the study of Nitrososphaera-like microorganisms in cold springs on the Qinghai-Tibetan Plateau [35]. As for AOB sequences, the Nitrosospira clades were found to be more advantageous in our study. Similar results were also found in cold springs on the Tibetan plateau (Nitrosospira was account for $69.2 \%$ in AOB sequences) [35]. Previous studies reveal a phenomenon that Nitrosospira-like microbes was dominant in sediments from high-elevation habitats (Qinghai-Tibetan plateau, Yuan plateau, and Andean wetland) [35-37]. Besides, it is reported that the Nitrosospira group dominated at stations with a marine influence [38], which could explain why the local conductivity of soil and water has a prominent role in shaping AOB community.

\subsection{Different Abundance but Similar $\alpha$-Diversity Pattern of Ammonia-Oxidizers}

The abundance differed substantially between the archaeal and bacterial amo $A$ genes. Specifically, the abundance of AOA was higher in riverine and lacustrine wetlands, while AOB amoA gene dominated in palustrine wetlands. Generally, it is widely accepted that AOA prefer to survive in low $\mathrm{NH}_{4}{ }^{+}$concentration [39-42]. In this study, the numerical advantage of AOB versus AOA in palustrine wetlands might be attributed to the higher soil $\mathrm{NH}_{4}{ }^{+}$concentration $\left(0.393 \sim 5.875 \mathrm{mg} \mathrm{kg}^{-1}\right)$ in palustrine wetlands, as compared to riverine $\left(\mathrm{NH}_{4}{ }^{+}: 0.201 \sim 1.121 \mathrm{mg} \mathrm{kg}^{-1}\right)$ and lacustrine wetlands $\left(\mathrm{NH}_{4}{ }^{+}\right.$: $\left.0.247 \sim 1.708 \mathrm{mg} \mathrm{kg}^{-1}\right)$. Particularly, these were two palustrine samples with the highest abundances of AOB in all samples, which also had the two highest $\mathrm{NH}_{4}{ }^{+}$concentrations in all of the samples (Online Resource 1). Interestingly, numerous studies have reported that AOA are typically more abundant than AOB in natural wetlands, such as lake sediments [39,43,44] and marine environment [45-48], while AOB outnumber AOA was mainly observed in several high-elevation lakes [42,49,50] or artificial ecosystem, such as constructed wetlands [51], wastewater treatment plants [52], and bioreactors [53]. The findings of this study suggest that additional characteristics that are specific to high-elevation habitats may play an important role in shaping AOA and AOB community structure.

The copy numbers of $\mathrm{AOA}$ and $\mathrm{AOB}$ were detected in average of $2.63 \times 10^{4}$ and $9.73 \times 10^{3}$ copies $\mathrm{g}^{-1}$ in the wetlands of the Qinghai-Tibetan Plateau, prodigiously lower than those $\left(1.34 \times 10^{5}\right.$ and $1.36 \times 10^{4}$ copies $\left.\mathrm{g}^{-1}\right)$ in lakes in the Yangtze River basin of China, respectively [54,55]. A recent study reported AOA abundance values that ranged from $10^{4}$ to $10^{9}$ copies $^{-1}$ from aquatic ecosystems, including lakes, rivers, paddy fields, reservoirs, and swamps, from eight countries of all five continents [8]. The low temperature at the high-altitude conditions could account for this phenomenon. It has been suggested that AOA abundance was inversely correlated with elevation of lakes of the Sierra Nevada, USA [56]. Several studies also reported that the temperature appeared to be the crucial factor affecting the abundances of the ammonia-oxidizers in both natural and constructed wetlands [57-59].

When we separately analyzed both ammonia-oxidizers, there was almost no significant difference between every two types of wetland, except that the AOA abundance of riverine wetlands were much higher than those of other two types (the graphs on the top right of Figure 2). It is likely that the wetland type is not an important factor in determining the abundance of the ammonia-oxidizers in Qinghai-Tibetan Plateau. On the contrary, the alpha-diversities (measured as OTU richness, evenness and Shannon index) between each type of wetlands were different. In general, the diversities of AOA and $\mathrm{AOB}$ were lowest in lacustrine wetlands, and highest in riverine wetlands (Figure 4). This might be related to the salinity of the wetlands. Half of the lacustrine wetlands in this study are saline marshes and have an average water conductivity of $15,358 \mu \mathrm{S} \mathrm{cm}{ }^{-1}$. The inference was supported 
by the negatively correlation between OTU richness, Shannon index, and the conductivity of water and soil (Online Resource 7). These findings suggested that conductivity largely contributed to the alpha-diversity of ammonia-oxidizers, which was in agreement with other researches. For instance, studies targeting the ammonia-oxidizing bacteria in the Chesapeake Bay [60] and MA estuaries [61] exhibited that the increasing salinity leads to the loss of diversity of AOB.

\section{3. $A O A$ and $A O B$ Contributed Differently to Nitrification Activity}

The ammonia-oxidizing microbes play a crucial role in wetland biogeochemical processes of wetland. We found that the nitrification was more related with AOB than AOA in our investigated sites. The relative contribution of $\mathrm{AOA}$ and $\mathrm{AOB}$ to the nitrification has been debated since Leininger et al. first reported the dominance of AOA in soil [62]. For instance, in a four-year repeated ammonium-fertilized study, the PNR significantly correlated with AOB abundance, but not with AOA abundance [63]. Taylor et al. also detected that $\mathrm{AOB}$ explained the majority of the nitrification activity in cropped soils, while, in fallowed soils, AOA and AOB both contributed to PNR [64]. The subsequent study illustrated that the soil conditions and $\mathrm{NH}_{4}{ }^{+}$-availability in soils might explain the different contributions of AOA and $A O B$ to nitrification [65]. While in acidic soils, the changes in nitrification activities were reported driven by AOA abundance, but not AOB [66,67]. These contradictory results illustrated that AOA and AOB may differently contribute to the nitrification activity in heterogeneous environmental conditions.

\subsection{Environmental Factors Shaping the Pattern of AOM Composition}

The distance-decay relationship describes how the similarity in community assembly varies with the geographic distance that separates them, which has been widely used in spatial biodiversity studies $[49,68,69]$. In this study, a significant correlation was detected between community composition and spatial distance, and also between community composition and the environmental factor, which implies both geographic distance and environmental factors are important in forming the community assembly of AOM. However, the VPA results suggested that the environmental selection was likely to have a dominant role (Figure 6). Moreover, the environmental heterogeneity might strengthen the compositional variation over spaces, which tends to further enhance the distance-decay relationships (online resource 8).

Numerous studies have reported that oxygen concentration, salinity, $\mathrm{pH}$, ammonia concentration, and temperature most likely affect the abundance of AOA [70-72] and AOB [42,43,73]. The above results were mainly obtained in a specific environment, and few studies have focused on a wider range [8]. The sites that we examined covered a broad spectrum of longitude $\left(80.16 \sim 106.07^{\circ} \mathrm{E}\right)$, latitude $\left(28.16 \sim 37.46^{\circ} \mathrm{N}\right)$, and elevation $(254.4 \sim 5150.6 \mathrm{~m})$, thus providing us with the opportunity to examine a broad range of environmental influences on AOM community composition. Our results suggest a dominant role for climate factors (MAT and MAP) in shaping community composition across a wide variety of wetland sites and conditions.

Although the environmental factors have the dominant role both in AOA and AOB community compositions, the relative importance and the driving factors are different. Our results indicated that the AOB communities in the Qinghai-Tibetan Plateau were more sensitive to changes in local environments than the AOA communities, which was consistent with other studies in Yangtze River [55] and in East Asian paddy soils [74]. Evolutionary considerations suggest that AOA can grow under the conditions of extreme salinity, temperature, and $\mathrm{pH}$, and other conditions that are not suitable for the growth of AOB [43]. Moreover, the oligotrophic AOA could compete with bacteria for ammonia [11]. Therefore, AOA have a more versatile metabolism than $\mathrm{AOB}$, and it might be adapted to a broader range of environments [62].

Clearly, these results highlight that the environmental factors have a prominent role in shaping the ammonia-oxidizer community patterns, but the drivers are different in AOA and AOB. It expands the ideas in wetland management that the characteristics of microorganism communities, especially those 
that are heavily involved in biogeochemical cycles, will serve as effective bioindicators to assess wetland trophic status and they will provide a potential application in the monitoring of wetlands $[75,76]$.

\section{Conclusions}

The compositions and structures of $\mathrm{AOA}$ and $\mathrm{AOB}$ communities are of importance to the nitrification. However, less is known regarding the ammonia-oxidizer community in high-elevation wetland ecosystems. Here, we examined the AOM community compositions in a large-scale survey across the Qinghai-Tibetan Plateau. We found a strong heterogeneity in terms of the abundance, community, and activity of ammonia oxidizers of $\mathrm{AOA}$ and $\mathrm{AOB}$ in sediments from three types of wetland. The copy numbers of both archaeal and bacterial amoA genes were prodigiously lower in these high-elevation wetlands than detected in some previous studies in wetlands. AOA were the main ammonia oxidizers in riverine and lacustrine wetlands, while $\mathrm{AOB}$ dominated in palustrine wetlands. The net nitrification rate had a significant correlation to $\mathrm{AOB}$, but not $\mathrm{AOA}$ abundance. The environmental conditions, but not spatial distance, have a dominant role in shaping the pattern of ammonia-oxidizer communities. Two climate factors (MAT and MAP) showed a strong impact on the total abundance of the archaeal amoA functional gene, while MAT and more soil conditions (conductivity and plant richness, $\mathrm{pH}$ and $\mathrm{TN}$ ) were significantly correlated with the bacterial amoA functional gene. Further research should be conducted in order to reveal the role of complete nitrifiers (comammox) in the high-elevation wetlands, which were found as a novel amoA sequence group in recent years.

Supplementary Materials: Supplementary materials can be found at http://www.mdpi.com/2076-2607/8/6/933/s1.

Author Contributions: W.Z., W.L. and G.L. designed the study; X.J., J.O. and B.L. performed the field sampling and laboratory analyses, W.Z., X.J. and G.L. analyzed the data; W.Z., W.L. and G.L. wrote the manuscript. All authors read and approved the final manuscript.

Funding: This work was supported by the National Natural Science Foundation of China (No. 31971479), Youth Innovation Promotion Association of CAS (No. 2017388), Key Strategic Program, CAS (Grant No. ZDRW-ZS-2017-3-2).

Acknowledgments: The authors would like to thank Lu Yao, Ziqian Xiong, Han Liu, Wei Xing and Wenyang Li for their assistances with the field sampling and laboratory analyses.

Conflicts of Interest: The authors declare no conflict of interest.

\section{References}

1. Stein, L.Y. Insights into the physiology of ammonia-oxidizing microorganisms. Curr. Opin. Chem. Biol. 2019, 49, 9-15. [CrossRef] [PubMed]

2. Kowalchuk, G.A.; Stephen, J.R. Ammonia-oxidizing bacteria: A model for molecular microbial ecology. Annu. Rev. Microbiol. 2001, 55, 485-529. [CrossRef] [PubMed]

3. Prosser, J.I.; Nicol, G.W. Relative contributions of archaea and bacteria to aerobic ammonia oxidation in the environment. Environ. Microbiol. 2008, 10, 2931-2941. [CrossRef] [PubMed]

4. Hu, H.W.; Chen, D.; He, J.Z. Microbial regulation of terrestrial nitrous oxide formation: Understanding the biological pathways for prediction of emission rates. FEMS Microbiol. Rev. 2015, 39, 729-749. [CrossRef]

5. Nicol, G.W.; Leininger, S.; Schleper, C.; Prosser, J.I. The influence of soil pH on the diversity, abundance and transcriptional activity of ammonia oxidizing archaea and bacteria. Environ. Microbiol. 2008, 10, 2966-2978. [CrossRef]

6. Verhamme, D.T.; Prosser, J.I.; Nicol, G.W. Ammonia concentration determines differential growth of ammonia-oxidizing archaea and bacteria in soil microcosms. ISME J. 2011, 5, 1067-1071. [CrossRef]

7. Zhang, Y.; Chen, L.; Dai, T.; Tian, J.; Wen, D. The influence of salinity on the abundance, transcriptional activity, and diversity of AOA and AOB in an estuarine sediment: A microcosm study. Appl. Microbiol. Biotechnol. 2015, 99, 9825-9833. [CrossRef]

8. Wang, W.; Liu, W.; Wang, S.; Wang, M.; Long, X.; Zhu, G. Abundance, contribution, and possible driver of ammonia-oxidizing archaea (AOA) in various types of aquatic ecosystems. J. Soil Sediment. 2019, 19, 2114-2125. [CrossRef] 
9. He, H.; Miao, Y.; Zhang, L.; Chen, Y.; Gan, Y.; Liu, N.; Dong, L.; Dai, J.; Chen, W. The structure and diversity of nitrogen functional groups from different cropping systems in Yellow River Delta. Microorganisms 2020, 8 , 424-445. [CrossRef]

10. Zhang, S.; Qin, W.; Xia, X.; Xia, L.; Li, S.; Zhang, L.; Bai, Y.; Wang, G. Ammonia oxidizers in river sediments of the Qinghai-Tibet Plateau and their adaptations to high-elevation conditions. Water Res. 2020, 173, 115589-115596. [CrossRef]

11. Martens-Habbena, W.; Berube, P.M.; Urakawa, H.; Urakawa, H.; De La Torre, J.R.; Stahl, D.A. Ammonia oxidation kinetics determine niche separation of nitrifying Archaea and Bacteria. Nature 2009, 461, 976-979. [CrossRef] [PubMed]

12. Erguder, T.H.; Boon, N.; Wittebolle, L.; Marzorati, M.; Verstraete, W. Environmental actors shaping the ecological niches of ammonia oxidizing archaea. FEMS Microbiol. Rev. 2009, 33, 855-869. [CrossRef] [PubMed]

13. Kits, K.D.; Sedlacek, C.J.; Lebedeva, E.V.; Han, P.; Bulaev, A.; Pjevac, P.; Daebeler, A.; Romano, S.; Albertsen, M.; Stein, L.Y.; et al. Kinetic analysis of a complete nitrifier reveals an oligotrophic lifestyle. Nature 2017, 549, 269-272. [CrossRef]

14. Mukhtar, H.; Lin, Y.; Lin, C.; Lin, Y. Relative abundance of ammonia oxidizing Archaea and Bacteria influences soil nitrification responses to temperature. Microorganisms 2019, 7, 526-539. [CrossRef]

15. Li, M.; Cao, H.L.; Hong, Y.G.; Gu, J.D. Spatial distribution and abundances of ammonia-oxidizing. archaea (AOA) and ammonia-oxidizing bacteria (AOB) in mangrove sediments. Appl. Microbiol. Biotechnol. 2011, 89, 1243-1254. [CrossRef] [PubMed]

16. Zhang, S.; Xia, X.; Li, S.; Zhang, L.; Wang, G.; Li, M.; Shi, Y.; Chen, N. Ammonia oxidizers in high-elevation rivers of the Qinghai-Tibet Plateau display distinctive distribution patterns. Appl. Environ. Microbiol. 2019, 85, e01701-e01719. [CrossRef]

17. Yu, C.; Zhang, Y.; Claus, H.; Zeng, R.; Zhang, X.; Wang, J. Ecological and environmental issues faced by a developing Tibet. Environ. Sci. Technol. 2012, 46, 1979-1980. [CrossRef]

18. Yang, Y.; Liu, G.; Ye, C.; Liu, W. Bacterial community and climate change implication affected the diversity and abundance of antibiotic resistance genes in wetlands on the Qinghai-Tibetan Plateau. J. Hazard. Mater. 2019, 361, 283-293. [CrossRef]

19. Shang, Z.; Feng, Q.; Wu, G.; Ren, G.; Long, R. Grasslandification has significant impacts on soil carbon, nitrogen and phosphorus of alpine wetlands on the Tibetan Plateau. Ecol. Eng. 2013, 58, 170-179. [CrossRef]

20. Alberta Wetland Identification and Delineation Directive. Applied Wetlands Science and Technology; CRC Press: Boca Raton, FL, USA, 2000.

21. Hijmans, R.J.; Cameron, S.E.; Parra, J.L.; Jones, P.G.; Jarvis, A. Very high-resolution interpolated climate surfaces for global land areas. Int. J. Climatol. 2005, 25, 1965-1978. [CrossRef]

22. Liu, W.Z.; Yao, L.; Wang, Z.X.; Xiong, Z.; Liu, G. Human land uses enhance sediment denitrification and $\mathrm{N}_{2} \mathrm{O}$ production in Yangtze lakes primarily by influencing lake water quality. Biogeosciences 2015, 12, 6059-6070. [CrossRef]

23. Hart, S.C.; Stark, J.M.; Davidson, E.A.; Firestone, M.K. Nitrogen mineralization, immobilization, and nitrification. In Methods of Soil Analysis: Part. 2-Microbiological and Biochemical Properties; Soil Science Society of America: Madison, WS, USA, 1994; pp. 985-1018.

24. Fierer, N.; Carney, K.M.; Horner-Devine, M.C.; Megonigal, J.P. The biogeography of ammonia-oxidizing bacterial communities in soil. Microbial. Ecol. 2009, 58, 435-445. [CrossRef] [PubMed]

25. Rotthauwe, J.H.; Witzel, K.P.; Liesack, W. The ammonia monooxygenase structural gene amo $A$ as a functional marker: Molecular fine-scale analysis of natural ammonia-oxidizing populations. Appl. Environ. Microbiol. 1997, 63, 4704-4712. [CrossRef] [PubMed]

26. Katoh, K.; Misawa, K.; Kuma, K.I.; Miyata, T. MAFFT: A novel method for rapid multiple sequence alignment based on fast Fourier transform. Nucleic Acids Res. 2002, 30, 3059-3066. [CrossRef] [PubMed]

27. Schloss, P.D.; Westcott, S.L.; Ryabin, T.; Hall, J.R.; Hartmann, M.; Hollister, E.B.; Lesniewski, R.A.; Oakley, B.B.; Parks, D.H.; Robinson, C.J.; et al. Introducing mothur: Opensource, platform-independent, community-supported software for describing and comparing microbial communities. Appl. Environ. Microbiol. 2009, 75, 7537-7541. [CrossRef] [PubMed]

28. Stecher, G.; Kumar, S.; Tamura, K. MEGA7: Molecular Evolutionary Genetics Analysis version 7.0 for bigger datasets. Mol. Biol. Evol. 2016, 33, 1870-1874. 
29. De Vargas, C.; Audic, S.; Henry, N.; Decelle, J.; Mahé, F.; Logares, R.; Lara, E.; Berney, C.; Bescot, N.L.; Probert, I.; et al. Eukaryotic plankton diversity in the sunlit ocean. Science 2015, 348, 1261605-1261615. [CrossRef]

30. Oksanen, J.; Blanchet, F.G.; Kindt, R.; Legendre, P.; Minchin, P.R.; O’hara, R.; Simpson, G.L.; Solymos, P.; Stevens, M.H.H.; Wagner, H.M. Vegan: Community Ecology Package; R Package Version 2.3-5; R Foundation: Viena, Austria, 2013.

31. Lozupone, C.; Knight, R. UniFrac: A new phylogenetic method for comparing microbial communities. Appl. Environ. Microbiol. 2005, 71, 8228-8235. [CrossRef]

32. Dray, S.; Legendre, P.; Peres-Netoac, P.R. Spatial modelling: A comprehensive framework for principal coordinate analysis of neighbour matrices (PCNM). Ecol. Model. 2006, 25, 483-493. [CrossRef]

33. Smith, T.W.; Lundholm, J.T. Variation partitioning as a tool to distinguish between niche and neutral processes. Ecography 2010, 33, 648-655. [CrossRef]

34. Johnson, J.W. A heuristic method for estimating the relative weight of predictor variables in multiple regression. Multivar. Behav. Res. 2000, 35,1-19. [CrossRef] [PubMed]

35. Peng, C.; Jiang, H.C.; Huang, L.Q.; Hou, W.G.; Yang, J.; Wang, S.; Huang, Q.Y.; Deng, S.C.; Dong, H.L. Abundance and diversity of ammonia-oxidizing bacteria and archaea in cold springs on the Qinghai-Tibet Plateau. Geomicrobiol. J. 2013, 30, 530-539. [CrossRef]

36. Liu, Y.; Zhang, J.X.; Zhang, X.L.; Xie, S.G. Depth-related changes of sediment ammonia-oxidizing microorganisms in a high-altitude freshwater wetland. Appl. Microbiol. Biotechnol. 2014, 98, 5697-5707. [CrossRef] [PubMed]

37. Molina, V.; Dorador, C.; Fernández, C.; Bristow, L.; Eissler, Y.; Hengst, M.; Hernandez, K.; Olsen, L.M.; Harrod, C.; Marchant, F.; et al. The activity of nitrifying microorganisms in a high-altitude Andean wetland. FEMS Microbiol. Ecol. 2018, 94. [CrossRef]

38. Freitag, T.E.; Chang, L.; Prosser, J.I. Changes in the community structure and activity of betaproteobacterial ammonia-oxidizing sediment bacteria along a freshwater-marine gradient. Environ. Microbiol. 2006, 8, 684-696. [CrossRef]

39. Herrmann, M.; Saunders, A.M.; Schramm, A. Effect of lake trophic status and rooted macrophytes on community composition and abundance of ammonia-oxidizing prokaryotes in freshwater sediments. Appl. Environ. Microbiol. 2009, 75, 3127-3136. [CrossRef] [PubMed]

40. Sims, A.; Horton, J.; Gajaraj, S.; Miles, R.J.; Mueller, R.; Reed, R.; Hu, Z. Temporal and spatial distributions of ammonia-oxidizing archaea and bacteria and their ratio as an indicator of oligotrophic conditions in natural wetlands. Water Res. 2012, 46, 4121-4129. [CrossRef]

41. Bollmann, A.; Bullerjahn, G.S.; McKay, R.M. Abundance and diversity of ammonia-oxidizing archaea and bacteria in sediments of trophic end members of the Laurentian Great Lakes, Erie and Superior. PLoS ONE 2014, 9, e97068. [CrossRef]

42. Yang, Y.; Li, N.; Zhao, Q.; Yang, M.; Wu, Z.; Xie, S.; Liu, Y. Ammonia-oxidizing archaea and bacteria in water columns and sediments of a highly eutrophic plateau freshwater lake. Environ. Sci. Pollut. Res. 2016, 23, 15358-15369. [CrossRef]

43. Hou, J.; Song, C.; Cao, X.; Zhou, Y. Shifts between ammonia-oxidizing bacteria and archaea in relation to nitrification potential across trophic gradients in two large Chinese lakes (Lake Taihu and Lake Chaohu). Water Res. 2013, 47, 2285-2296. [CrossRef]

44. Zhao, D.; Zeng, J.; Wan, W.; Liang, H.; Huang, R.; Wu, Q.L. Vertical distribution of ammonia-oxidizing archaea and bacteria in sediments of a eutrophic lake. Curr. Microbiol. 2013, 67, 327-332. [CrossRef] [PubMed]

45. Nakagawa, T.; Mori, K.; Kato, C.; Takahashi, R.; Tokuyama, T. Distribution of cold-adapted ammonia-oxidizing microorganisms in the deep-ocean of the northeastern Japan Sea. Microbes Environ. 2007, 22, 365-372. [CrossRef]

46. Bouskill, N.J.; Eveillard, D.; Chien, D.; Jayakumar, A.; Ward, B.B. Environmental factors determining ammonia-oxidizing organism distribution and diversity in marine environments. Environ. Microbiol. 2012, 14, 714-729. [CrossRef] [PubMed]

47. Newell, S.E.; Fawcett, S.E.; Ward, B.B. Depth distribution of ammonia oxidation rates and ammonia-oxidizer community composition in the Sargasso Sea. Limnol. Oceanogr. 2013, 58, 1491-1500. [CrossRef] 
48. Lipsewers, Y.A.; Bale, N.J.; Hopmans, E.C.; Schouten, S.; Damste, J.S.S.; Villanueva, L. Seasonality and depth distribution of the abundance and activity of ammonia oxidizing microorganisms in marine coastal sediments (North Sea). Front. Microbiol. 2014, 5, 472-483.

49. Yang, Y.Y.; Shan, J.W.; Zhang, J.X.; Zhang, X.L.; Xie, S.G.; Liu, Y. Ammonia- and methane-oxidizing microorganisms in high-altitude wetland sediments and adjacent agricultural soils. Appl. Microbiol. Biotechnol. 2014, 98, 10197-10209. [CrossRef]

50. Liu, Y.; Zhang, J.X.; Zhao, L.; Li, Y.Z.; Dai, Y.; Xie, S.G. Distribution of sediment ammonia-oxidizing microorganisms in plateau freshwater lakes. Appl. Microbiol. Biotechnol. 2015, 99, 4435-4444. [CrossRef]

51. Su, Y.; Wang, W.D.; Wu, D.; Huang, W.; Wang, M.Z.; Zhu, G.B. Stimulating ammonia oxidizing bacteria (AOB) activity drives the ammonium oxidation rate in a constructed wetland (CW). Sci. Total Environ. 2018, 624, 87-95. [CrossRef]

52. Gao, J.F.; Luo, X.; Wu, G.X.; Li, T.; Peng, Y.Z. Quantitative analyses of the composition and abundance of ammonia-oxidizing archaea and ammonia-oxidizing bacteria in eight full-scale biological wastewater treatment plants. Bioresour. Technol. 2013, 138, 285-296. [CrossRef]

53. Wells, G.F.; Park, H.D.; Yeung, C.H.; Eggleston, B.; Francis, C.A.; Criddle, C.S. Ammonia-oxidizing communities in a highly aerated full scale activated sludge bioreactor: Betaproteobacterial dynamics and low relative abundance of Crenarchaea. Environ. Microbiol. 2009, 11, 2310-2328. [CrossRef]

54. Jiang, X.; Wu, Y.; Liu, G.; Liu, W.; Lu, B. The effects of climate, catchment land use and local factors on the abundance and community structure of sediment ammonia-oxidizing microorganisms in Yangtze Lakes. AMB Express 2017, 7, 173-185. [CrossRef] [PubMed]

55. Yao, L.; Chen, C.; Liu, G.; Li, F.; Liu, W. Environmental factors, but not abundance and diversity of nitrifying microorganisms, explain sediment nitrification rates in Yangtze Lakes. RSC Adv. 2018, 8, 1875-1883. [CrossRef]

56. Hayden, C.J.; Beman, J.M. High abundances of potentially active ammonia-oxidizing bacteria and archaea in oligotrophic, high-altitude lakes of the Sierra Nevada, California, USA. PLoS ONE 2014, 9, e111560. [CrossRef] [PubMed]

57. Sims, A.; Gajaraj, S.; Hu, Z. Seasonal population changes of ammonia-oxidizing organisms and their relationship to water quality in a constructed wetland. Ecol. Eng. 2012, 40, 100-107. [CrossRef]

58. Faulwetter, J.L.; Burr, M.D.; Parker, A.E.; Stein, O.R.; Camper, A.K. Influence of season and plant species on the abundance and diversity of sulfate reducing bacteria and ammonia oxidizing bacteria in constructed wetland microcosms. Microb. Ecol. 2013, 65, 111-127. [CrossRef]

59. Morlon, H.; Chuyong, G.; Condit, R.; Hubbell, S.; Kenfack, D.; Thomas, D.; Valencia, R.; Green, J.L. A general framework for the distance-decay of similarity in ecological communities. Ecol. Lett. 2008, 11, 904-917. [CrossRef]

60. Bernhard, A.E.; Donn, T.; Giblin, A.E.; Stahl, D.A. Loss of diversity of ammonia-oxidizing bacteria correlates with increasing salinity in an estuary system. Environ. Microbiol. 2005, 7, 1289-1297. [CrossRef]

61. Bernhard, A.E.; Tucker, J.; Giblin, A.E.; Stahl, D.A. Functionally distinct communities of ammonia-oxidizing bacteria along an estuarine salinity gradient. Environ. Microbiol. 2007, 9, 1439-1447. [CrossRef]

62. Leininger, S.; Urich, T.; Schloter, M.; Schwark, L.; Qi, J.; Nicol, G.W.; Prosser, J.I.; Schuster, S.C.; Schleper, C. Archaea predominate among ammonia-oxidizing prokaryotes in soils. Nature 2006, 442, 806-809. [CrossRef]

63. Ouyang, Y.; Norton, J.M.; Stark, J.M.; Reeve, J.R.; Habteselassie, M.Y. Ammonia-oxidizing bacteria are more responsive than archaea to nitrogen source in an agricultural soil. Soil Biol. Biochem. 2016, 96, 4-15. [CrossRef]

64. Taylor, A.E.; Zeglin, L.H.; Dooley, S.; Myrold, D.D.; Bottomley, P.J. Evidence for different contributions of archaea and bacteria to the ammonia-oxidizing potential of diverse Oregon Soils. Appl. Environ. Microbiol. 2010, 76, 7691-7698. [CrossRef]

65. Taylor, A.E.; Zeglin, L.H.; Wanzek, T.A.; Myrold, D.D.; Bottomley, P.J. Dynamics of ammonia-oxidizing archaea and bacteria populations and contributions to soil nitrification potentials. ISME J. 2012, 6, 2024-2032. [CrossRef]

66. Zhang, L.M.; Hu, H.W.; Shen, J.P.; He, J.Z. Ammonia-oxidizing archaea have more important role than ammonia-oxidizing bacteria in ammonia oxidation of strongly acidic soils. ISME J. 2012, 6, 1032-1045. [CrossRef] [PubMed] 
67. Qin, H.L.; Yuan, H.Z.; Zhang, H.; Zhu, Y.J.; Yin, C.M.; Tan, Z.J.; Wu, J.S.; Wei, W.X. Ammonia-oxidizing archaea are more important than ammonia-oxidizing bacteria in nitrification and $\mathrm{NO}_{3}-\mathrm{N}$ loss in acidic soil of sloped land. Biol. Fertil. Soils 2013, 49, 767-776. [CrossRef]

68. Hanson, C.A.; Fuhrman, J.A.; Horner-Devine, M.C.; Martiny, J.B.H. Beyond biogeographic patterns: Processes shaping the microbial landscape. Nat. Rev. Microbiol. 2012, 10, 497-506. [CrossRef] [PubMed]

69. Wang, X.B.; Lu, X.T.; Yao, J.; Wang, Z.W.; Deng, Y.; Cheng, W.X.; Zhou, J.Z.; Han, X.G. Habitat-specific patterns and drivers of bacterial $\beta$-diversity in China's drylands. ISME J. 2017, 11, 1345-1358. [CrossRef]

70. Shen, J.P.; Zhang, L.M.; Di, H.J.; He, J.Z. A review of ammonia-oxidizing bacteria and archaea in Chinese soils. Front. Microbiol. 2012, 3, 296-302. [CrossRef] [PubMed]

71. Prosser, J.I.; Nicol, G.W. Archaeal and bacterial ammonia-oxidisers in soil: The quest for niche specialization and differentiation. Trends Microbiol. 2012, 20, 523-531. [CrossRef]

72. Pett-Ridge, J.; Petersen, D.G.; Nuccio, E.; Firestone, M.K. Influence of oxic/anoxic fluctuations on ammonia oxidizers and nitrification potential in a wet tropical soil. FEMS Microbiol. Ecol. 2013, 85, 179-194. [CrossRef]

73. Liu, B.; Li, Y.M.; Zhang, J.P.; Zhou, X.H.; Wu, C.D. Abundance and diversity of ammonia-oxidizing microorganisms in the sediments of Jinshan Lake. Curr. Microbiol. 2014, 69, 751-757. [CrossRef]

74. Mukhtar, H.; Lin, Y.P.; Anthony, J. Ammonia oxidizing archaea and bacteria in east Asian paddy soils-A mini review. Environments 2017, 4, 84-92. [CrossRef]

75. Sims, A.; Zhang, Y.Y.; Galaraj, S.; Brown, P.B.; Hu, Z.Q. Toward the development of microbial indicators for wetland assessment. Water Res. 2013, 47, 1711-1725. [CrossRef] [PubMed]

76. Urakawa, H.; Bernhard, A.E. Wetland management using microbial indicators. Ecol. Eng. 2017, 108, 456-476. [CrossRef]

(C) 2020 by the authors. Licensee MDPI, Basel, Switzerland. This article is an open access article distributed under the terms and conditions of the Creative Commons Attribution (CC BY) license (http://creativecommons.org/licenses/by/4.0/). 